\title{
Research on Double Helix Structure of Investment Undergraduate Major Set and the Optimization Exploration of Regional Industrial Structure under the Environment of "Double Creation"
}

\author{
Wenhui Ding, Lei Wang \\ Guangdong University of Science and Technology, Dongguan, Guangdong, 523000
}

Keywords: Double Helix Structure, Investment Undergraduate Major Set, Optimization Exploration of Regional Industrial Structure, Environment of "Double Creation"

\begin{abstract}
Under the circumstance of double creation, undergraduate education in colleges and universities, as a type of education closely related to social and economic development, analyzes whether its specialty setting is compatible with regional industrial structure and whether higher education fully exerts its effect on serving social and economic development. It is also related to the prosperity and development of higher education itself. The adjustment and optimization of regional industrial structure promote economic growth, and the technological structure is continuously optimized and upgraded, leading to changes in the demand for talent in the labor market and proposing higher demands on personnel training in colleges and universities. Therefore, it is of far-reaching significance to study the interaction mechanism between the two and to explore the optimization direction of undergraduate majors in the process of regional industrial structure adjustment and optimization.
\end{abstract}

\section{Introduction}

The essence of higher education is to train qualified personnel to serve the society and promote the all-round economic and social development. The professional setting of colleges and universities is related to the quality, specification and mode of personnel training, affecting the structure of talent supply and the structure of social technology, and then to the optimization and adjustment of industrial structure [1]. In turn, the readjustment of the industrial structure will optimize and promote the regional economic growth, and the government will thus obtain more financial revenue, which will inevitably increase spending on education and promote the development of higher education. At the same time, the key to the optimization of industrial structure is advanced technology. Innovation and skills put forward higher requirements. Existing research shows that there is a significant correlation between the development of higher education and the adjustment of industrial structure, and there is a long-term development relationship. Thus it can be seen that the optimization of professional settings in colleges and universities is not only the inherent requirement of the development of higher education but also the demand of further economic and social development. However, at present, there are still many problems in the professional setting of undergraduate colleges and universities that cultivate talents with their professional carriers and methods. Now in the context of the transformation of local colleges and universities, the professional setting of colleges and universities is bound to face new reforms. Looking at the existing research, we find that the adjustment of industrial structure and the development of higher education interact and promote each other. However, there are few researches on the mechanism of how industrial structure optimization and undergraduate specialty setting influence each other and promote each other. Therefore, it is necessary to carry out relevant research to explore the double helix development relationship between industrial structure and professional setting in the process of industrial structure adjustment and upgrading in Inner Mongolia Autonomous Region, so as to clarify the changing direction of talent demand in the future, optimize professional setting reasonably and realize talents step by step Strong area goal. 


\section{The Overview of "Double Create"}

"Double hit", simply put, that is, "public entrepreneurship, innovation of many" [1]. Mass entrepreneurship that is universal entrepreneurship, that is, people in all fields together, together through market research and other means to identify the current more potential for development of the industry, through its feasibility study of entrepreneurship, the establishment of entrepreneurial programs, and its implementation A way to start a business. In the past, entrepreneurship had a high demand for capital. In the era of mass entrepreneurship, the demand for capital for entrepreneurial capital in society was greatly reduced. The development of SMEs is proof of this. At this time, the development of talent value, Provides a convenient platform for social progress and economic prosperity of great significance. Innovations, that is, innovation for all, require everyone to establish an innovative concept and apply it to practical work to make it worthwhile. The environment of "double creation" is a symbol of thinking and technology emancipation. It is also a concrete manifestation of social economy and cultural development, laying a very solid policy foundation for the pioneering of talents [2].

\section{Related Research on Investment}

Investment professional is to adapt to China's diversification of investment subjects, diversification of investment patterns, decentralized investment scale, professional investment behavior, professional investment activities arising from the background of a new profession. As a discipline, investment research is a systematic study of investment so as to conduct scientific investment activities. The core of it is guided by the principle of maximizing utility, and obtains the optimal equilibrium solution of personal wealth allocation. Professionalization of investment and investment is an inevitable trend in the development of the investment industry.

With the continuous economic development in our country and our province, we urgently need to cultivate a large number of applied talents with professional operation skills and other operational skills. Therefore, students of applied undergraduate colleges require both theoretical knowledge and strong practical ability as well as Strong computer skills and job code of conduct. It has become an important task for us to construct a comprehensive simulation practice teaching research and practice system that comprehensively enhances students' applied skills and investment professional skills. Through the analysis, we found that the current practice teaching of investment major encountered more difficulties.

\section{The Double Helix Structure Model}

The double-helix structure model originated from DNA double helix structure in life science. In 1953, Watson and Crick simulated the first molecular model of DNA double helix structure with tin and iron wire. The so-called double helix is the shape of the DNA for the two main chains, the DNA backbone has two, they are like "twisty" around a common axis of the right hand direction hovering, parallel to each other to form a double helix conformation [3].

DNA double helix structure has three main features: First, the two DNA backbone relies on the formation of hydrogen bonds between the two bases together, $\mathrm{A}$ and $\mathrm{T}$ in the two hydrogen bonds Paired, G and C Paired with the action of three hydrogen bonds, thus the connection between $G$ and $\mathrm{C}$ is more stable. Second, the four bases are paired with each other under hydrogen bonding and the vertical stacking between two pairs of base pairs forms a double Helical structure, so DNA double helix structure is relatively stable, and hydrogen bonding is the key to maintain this stability; Third, in the principle of fixed base pairs, DNA double helix structure of the two main chain base sequence Complement each other, which means that as long as one of the chain to determine the base sequence, the base sequence of the other chain is determined, so only one of the main chain as a template, you can synthesize another copy The main chain, which shows that DNA double helix structure has the characteristics of replicability. 


\section{The Interaction between Industrial Structure and Professional Settings}

The theoretical basis of the relationship between the structure of higher education and the industrial structure is the internal and external laws of higher education proposed by Pan Maoyuan. The structure of higher education is the embodiment of internal laws. The industrial structure is the law of higher education with the external relations. According to the law of external relations of higher education proposed by Mr. Pan Maoyuan, the economic development is the foundation of the professional structure of colleges and universities. At the same time, the setting of the professional structure of colleges and universities promotes the development of productive forces. This kind of relationship is reflected in the changes of economic structure and industrial structure, which require that the professional structure of colleges and universities should be compatible with the economic structure. However, this adaptation is not without principles. Random adaptation and reasonable professional structure of colleges and universities are affected by economic, political and cultural changes and other factors; college professional structure and decided to train the talents of the professional direction, which affects the demand and supply of industrial demand among the state. If the number of professionals trained in colleges and universities exceeds the quantity required by the industry, there will be a phenomenon of oversupply of university graduates and an increase of unemployment rate, on the contrary, there will be a shortage of talents. Mr. Pan Maoyuan also pointed out that the main factors restricting higher education also include the level of development of science and technology and productivity, so the study of the internal and external relations of higher education must pay attention to the relationship between science and technology and productivity. In response to the problems facing the process of higher education reform, the use of internal and external laws of education to conduct research and analysis plays an important guiding role in deepening the reform and development of higher education in the future [4].

Professional settings related to the quality of personnel training in colleges and universities, specifications and models. The scale of personnel training in colleges and universities is related to the demand of social talents and the quality of personnel training is related to the efficiency of social labor. All these factors will indirectly contain the optimization and upgrading of industrial structure.

First, the proportion of personnel training affects the structure of talent supply. Tin-Chun Lin, based on data from Taiwan's economic growth from 1996 to 2000, explores whether different disciplines have different impacts on economic development through different industries, that is, using regression models to examine how higher education graduates from different disciplines affect economic output. The results of the study confirm that the most prominent contributions to economic growth are from the social sciences, anthropology, commerce, agriculture, engineering and natural sciences. This coincided with the current trend of China's industrialization. Based on the contributions of engineering and natural science majors, the proportion of such professions in colleges and universities will be raised accordingly, so that such professionals are adequately supplied and meet the needs of industrial restructuring.

Second, the quality of personnel training affects the industrial technological structure and social labor productivity. Colleges and universities rely on professional carriers to cultivate various types of technical personnel, optimize the professional structure, improve the personnel training system, highlighting the professional characteristics and other measures to optimize the knowledge structure of the labor force, so that effective transfer of resources between industries, industrial rational allocation of resources, continuous optimization of industrial technology structure. In addition, the personnel training system in colleges and universities emphasizes the cultivation of practical ability and encourages innovation, which has a certain positive impact on improving the labor productivity of various industrial departments. The improvement of labor productivity leads to income differences among industries, thus driving the changes in demand of various sectors in various industries and promoting the optimization and upgrading of industrial structure.

Thirdly, the cost of professional construction and the personal expected rate of return on investment in education affect the optimization of industrial structure. It is well-known that individuals tend to be low-cost and high-yielding things. When the labor force needs to be 
transferred from the primary industry to the secondary and tertiary industries due to the optimization of industrial structure, colleges and universities can reasonably reduce the number of personnel training corresponding to the primary industry or reduce the rate of return on investment in the profession, so that the supply and demand of talents can be balanced. Colleges and universities can also reduce the cost of industry-related, service-related professional tuition, increase the cost of professional construction improve the personal education expected return, to increase the number of students. As a result, under the premise of a constant total investment return rate of education, colleges and universities can indirectly promote the optimization of industrial structure by reasonably adjusting and optimizing professional settings. Fourth, the optimization of professional settings affects the optimization and upgrading of industrial structure. Optimization of professional settings is an inherent requirement for the development of higher education in order to improve the quality of higher education. Higher education itself belongs to the tertiary industry category. Therefore, optimizing professional settings and accelerating the development of higher education have promoted the optimization and upgrading of industrial structure.

The impact of industrial structure on the setting of specialties The optimization and upgrading of industrial structure accompanied by further division of labor and specialization brought about a larger employment market, increased resource allocation efficiency and labor productivity with technological innovation, and accelerated economic growth.

First, the study on the impact of industrial structure on higher education and professional settings is mainly reflected in the fact that the continuous optimization and adjustment of industrial structure has changed the structure of technology and the allocation of qualified personnel, which in turn has changed the structure of talent supply and demand and affected the cultivation of qualified personnel in higher education institutions. The development of regional economy relies on the upgrading of the industrial structure. The continuous optimization and readjustment of the industrial structure will bring about a flexible employment market. Therefore, there is a higher demand on the technical and professional knowledge of workers [5].

Second, the optimization and upgrading of industrial structure affect the government's financial expenditure on higher education. As a result, workers' incomes have risen, and government revenues have increased, implying that government spending on higher education has increased.

Third, the optimization and upgrading of the industrial structure affect the direction of higher education investment. In the process of industrial structure optimization and upgrading, factors of production flow to industries or industries with higher labor productivity. In order to maintain and improve the existing labor productivity, industries or industries with high labor productivity need to absorb more high-tech production factors in ways that raise wages and profits. As a result, with the gradual optimization of the industrial structure, factors of production, wages and profits will be redistributed and combined among industries, and the proportion of inputs and outputs of various industries will also change accordingly. Those higher education and higher education-related personnel training colleges and universities and then get a higher expected rate of return, will get more businesses and individuals of all ages and investment.

\section{Conclusions}

The key point of the link between the development of higher education and regional economic growth, the connection between the undergraduate specialty setting and the optimization of regional industrial structure lies in the changes of the relationship between supply and demand of talents and the structure of knowledge and technology of talented people. By setting undergraduate programs as an entry point, we can indirectly promote the development of regional industrial structure by promoting the specifications, levels and quality of personnel training in higher education. Based on the characteristics of DNA double helix structure, based on the interactive and balanced development of regional industrial structure optimization and higher education development, a double helix model of regional industrial structure optimization and undergraduate specialty setting was constructed. 


\section{References}

[1] Lu Fengqi, Mu Zhanjun, Xu Ruichen. Optimization and Analysis of Undergraduate Programs in Universities and Colleges in Inner Mongolia - From the Perspective of Industrial Structure Adjustment [J] Journal of Inner Mongolia Normal University (Education Science Edition), 2015 (09).55

[2] Liu Wanchen, Hu Yongxiang. Study on the Impact of Resident Consumption Structure Optimization on the Upgrading of Industrial Structure - Based on PVAR Model [J]. Business Economics Research. 2015 (20).325-326

[3] Lu Fengqi, Mou Zhanjun, Xu Ruichen. Regulation of Regional Industrial Structure and Optimization of Undergraduate Professional Setting - A Case Study of Inner Mongolia Autonomous Region [J]. Inner Mongolia Science \& Technology and Economy. 2015 (07).11-14

[4] Wang Hongqi, Yang Zhongji, An Ning. Study on the Cultivation Pattern and Its Application of Strategic Industries Emerging from the Perspective of Innovation Double Helix [J]. China Science \& Technology Forum. 2014 (08).88

[5] Xu Changqing. Research on the Optimization of Specialty Setup in Guangdong Universities Based on the Adjustment of Regional Industrial Structure [J]. Modern Education Science. 2014 (03).63-65 